\title{
ODZYSKIWANIE SKRADZIONYCH DÓBR KULTURY PO LATACH OD ICH KRADZIEŻY
}

\begin{abstract}
Streszczenie. W obecnych czasach popyt na dzieła sztuki i zabytki gwałtownie wzrasta, jednak liczba samych zabytków i dzieł sztuki nie zwiększa się wraz z tym popytem. Kradzież dzieła sztuki lub zabytku nie skutkuje utratą jego wartości, wręcz przeciwnie - wieloletnie przechowywanie powoduje dalszy wzrost jego wartości. Z tego względu dzieła sztuki i zabytki stanowią kuszący przedmiot przestępstwa. Sytuacja ta została dostrzeżona przez grupy przestępcze, które znają i wykorzystują potrzeby rynku kolekcjonerskiego. W latach 90. odnotowano wiele włamań do obiektów sakralnych, muzeów i domów prywatnych, w trakcie których przedmiotem przestępstwa były głównie dzieła sztuki. Obecnie można zaobserwować, że skradzione w tamtych latach zabytki coraz częściej pokazują się na rynku sztuki.
\end{abstract}

Słowa kluczowe: muzeum, kolekcja, kradzież, eksponat, kryminalistyka.

Coraz poważniejszym zagrożeniem związanym z rynkiem kolekcjonerskim jest przestępczość przeciwko zabytkom - mniej lub bardziej wyspecjalizowane grupy przestępcze lub pojedyncze osoby dokonujące przestępstw skierowanych w dobra kultury. Osoby te kierują się przede wszystkim pasją połączoną z chęcią łatwego, szybkiego zysku, realizując tym samym młodzieńcze marzenia o znalezieniu skarbu. Są one bardzo dobrze zorganizowane i przygotowane, korzystają z szeroko dostępnej literatury, informacji z mediów, a także Internetu. Nasilenie zainteresowania zabytkami i dziełami sztuki obserwujemy już od dłuższego czasu - dotyczy to różnego rodzaju placówek muzealnych, galerii, prywatnych kolekcji. Dochodzi też do grabieży zabytkowych przedmiotów znajdujących się pod ziemią oraz ich sprzedaży na terenie Polski i Europy. Łatwość dostępu do takich miejsc, niewielki nakład inwestycyjny oraz popyt na rynku zabytków powodują, że ten proceder stale się pogłębia. Na podstawie obserwacji rynku sztuki można stwierdzić, że skradzione przed laty dobra kultury coraz częściej pokazują się na współczesnym rynku sztuki, stając się przedmiotem obrotu handlowego. Należy podkreślić, że to kolekcjonerzy są głównymi nabywcami zabytków na rynku sztuki w Polsce, natomiast obrót zabytkami ruchomymi generuje bardzo duże zyski.

Zauważając ten problem i uwzględniając istnienie Europy bez granic, a także opierając się na doświadczeniach innych krajów, również w Polsce zaczęto tworzyć porozumienia uruchamiające mechanizmy pozwalające organom ścigania skutecznie walczyć z przestępczością na tej płaszczyźnie. W dniu 4 listopada

*Komenda Główna Policji, adam.ggg1@wp.pl. 
2004 r. podpisano porozumienie pomiędzy Ministrem Finansów, Ministrem Kultury, Komendantem Głównym Policji i Komendantem Głównym Straży Granicznej w sprawie współdziałania w zwalczaniu nielegalnego wywozu za granicę lub przywozu z zagranicy zabytków, poprzez udzielanie sobie wzajemnej pomocy w zakresie czynności kontrolnych, wymiany informacji, szkolenia i wymiany doświadczeń (Dziennik Urzędowy Komendy Głównej Policji 2004, Nr 21, poz. 135). Celem uzupełnienia powyższego porozumienia, w dniu 10 marca 2005 r. podpisano kolejne - pomiędzy Generalnym Konserwatorem Zabytków i Komendantem Głównym Policji w sprawie współdziałania w zakresie zapobiegania i zwalczania przestępczości skierowanej przeciwko zabytkom (Dziennik Urzędowy Komendy Głównej Policji 2005, Nr 6, poz. 29). Powyższe uregulowania pozwoliły na podpisanie w dniu 21 listopada 2006 r. porozumienia pomiędzy Komendantem Wojewódzkim Policji w Łodzi, Dyrektorem Izby Celnej w Łodzi, Wojewódzkim Konserwatorem Zabytków, Dyrektorem Archiwum Państwowego w Łodzi oraz Komendantem Nadwiślańskiego Oddziału Straży Granicznej w sprawie współdziałania w zakresie ochrony zabytków i materiałów archiwalnych oraz zwalczania ich nielegalnego wywozu za granicę i przywozu z zagranicy. Dla umożliwienia realizacji przyjętych założeń, w marcu 2007 r. kierownictwo Komendy Głównej Policji poleciło pilotażowo utworzyć w kilku komendach wojewódzkich Policji zespoły zajmujące się tym zagadnieniem, a w pozostałych powołać koordynatorów. Natomiast w samej Komendzie Głównej Policji funkcjonowanie rozpoczął Krajowy Zespół do Zwalczania Przestępczości Przeciwko Dziedzictwu Narodowemu, który w 2013 r. został rozwiązany. Zadania rozwiązanego Zespołu w Komendzie Głównej Policji przejęło dwóch koordynatorów, natomiast Zespoły w komendach wojewódzkich Policji działają do dnia dzisiejszego w strukturach wydziałów kryminalnych.

W Wydziale Kryminalnym Komendy Wojewódzkiej Policji w Łodzi, na mocy decyzji z dnia 7 maja 2007 r. powstał Zespół do Zwalczania Przestępczości Przeciwko Dziedzictwu Narodowemu, który działa do dnia dzisiejszego. Dzięki działaniom zespołu, od dnia jego powstania w województwie łódzkim w związku z przestępstwami przeciwko dziedzictwu narodowemu, zatrzymano około 57 osób, w tym 45 osób dokonujących zniszczenia i przywłaszczenia zabytków archeologicznych podczas nielegalnych poszukiwań1. Funkcjonariusze, dysponując odpowiednim przygotowaniem, wiedzą i doświadczeniem, działają we wszystkich wyżej wymienionych strukturach przede wszystkim na podstawie istniejących norm prawnych. Są to:

- ustawa z dnia 23 lipca 2003 r. o ochronie zabytków i opiece nad zabytkami (t.j. Dz. U. 2017, poz. 2187; dalej u.o.o.z.) - art. 23, 24a, 24d, 35, przepisy karne, art. 108-119;

\footnotetext{
${ }^{1}$ Opracowanie własne, informacje zebrane przez autora (stan na 24 października 2016 r.).
} 
- ustawa z dnia 6 czerwca 1997 r. - Kodeks karny (t.j. Dz. U. 2017, poz. 2204; dalej: k.k.) - art. 171, 262, 263, 278, 279, 284, 288, 291, 294, 295;

- ustawa z dnia 23 kwietnia 1964 r. - Kodeks cywilny (t.j. Dz. U. 2017, poz. 459 ; dalej: k.c.) - art. 184, 187, 189, 223;

- europejska konwencja o ochronie dziedzictwa archeologicznego z La Valetta z 16 stycznia 1992 r., ratyfikowana 13 grudnia 1995 r. (Dz. U. 1996, Nr 120, poz. 564);

- konwencja podpisana w Paryżu dotycząca podejmowania środków w celu zapobiegania nielegalnemu wywozowi, przywozowi i przenoszeniu własności dóbr kultury z 17 maja 1970 r. (Dz. U. 1974, Nr 20, poz. 106);

- ustawa z dnia 20 lutego 2015 r. o rzeczach znalezionych (Dz. U. 2015, poz. 397; dalej u.o.rz.z.) - art. 26;

- ustawa z dnia 21 maja 1999 r. o broni i amunicji (t.j. Dz. U. 2017, poz. 1839; dalej: u.o.b.a.) - art. 4, 5, 10.

Obecnie popyt na dzieła sztuki i zabytki gwałtownie wzrasta. Jak wiadomo, liczba samych zabytków i dzieł sztuki nie zwiększa się wraz z tym popytem. Kradzież dzieła sztuki lub zabytku nie powoduje jednak utraty jego wartości, wręcz przeciwnie - jego wieloletnie przechowywanie skutkuje dalszym wzrostem tej wartości. Tę sytuację wykorzystują grupy przestępcze, które znają potrzeby rynku kolekcjonerskiego. W latach 90. XX w. odnotowano na terenie Polski falę włamań do obiektów sakralnych, muzeów i domów prywatnych, w trakcie których przedmiotem przestępstwa były głównie dzieła sztuki. W 1993 r. z Muzeum w Górkach Wielkich skradziono 13 obrazów Juliusza i Wojciecha Kossaków. W 1996 r. w Muzeum Wsi Kieleckiej miała miejsce kradzież, w trakcie której utracono blisko 90 eksponatów (Kocewiak, Ogrodzki, Rulewicz 2002, 16-17). Wszystkie te eksponaty zostały zarejestrowane w katalogu utraconych zabytków, który od lipca 2005 r. funkcjonuje również w wersji internetowej na stronie: www.skradzionezabytki.pl. Zgodnie z zapisem art. 23 ust. 1 u.o.o.z., krajowy wykaz zabytków skradzionych lub wywiezionych za granicę niezgodnie z prawem stanowi narzędzie służące do identyfikacji i poszukiwań utraconych dóbr kultury (www.nimoz. pl). Jest on administrowany przez Narodowy Instytut Muzealnictwa i Ochrony Zbiorów (NIMOZ), który gromadzi również archiwalne foto-komunikaty oraz inne materiały niezbędne do identyfikacji zabytku. Są to dokumenty dotyczące spraw nawet sprzed kilkunastu lat, w których nie można już odtworzyć akt prowadzonych postępowań. Ponadto, jak pokazuje dotychczasowa praktyka, po dokonaniu kradzieży informacje o skradzionych przedmiotach często są publikowane w prasie i katalogach utraconych dzieł sztuki, co rozszerza możliwość dostępu do informacji o poszukiwanych dobrach kultury. Należy podkreślić, że w 2015 r. weszła w życie ustawa o rzeczach znalezionych. Artykułem 26 ustawy o rzeczach znalezionych wprowadzono zmiany w art. 223 k.c., dodając $\S 4$. Po zmianach art. $223 \S 4$ k.c. stanowi, iż roszczenie właściciela rzeczy wpisanej do krajowego rejestru utraconych dóbr kultury nie ulega przedawnieniu. Nowa ustawa doprecyzowała sporną kwestię dotyczącą przedawnienia roszczeń w przypadku zabytków 
i dzieł sztuki (Rudnicki, Rudnicka, Rudnicki 2016, 508-536). Zgodnie z nowelizacją ustawy o ochronie zabytków i opiece nad zabytkami, jakie po zmianach w 2015 r. wprowadziła ustawa o rzeczach znalezionych, taka sytuacja może mieć miejsce, gdy rzecz stanowiąca dobro narodowe zostanie utracona. Ustawodawca wprost wskazuje, iż roszczenie takie nie ulega przedawnieniu, gdy wskutek przestępstwa kradzieży (art. 278 k.k.), kradzieży z włamaniem (art. 279 k.k.), rozboju (art. 280 k.k.), kradzieży rozbójniczej (art. 281 k.k.), wymuszenia rozbójniczego (art. 282 k.k.), przywłaszczenia (art. 284 k.k.) kolekcja bądź pojedynczy element zbiorów, stanowiące według definicji prawnej muzealia, o których mowa w art. 21 ustawy z dnia 21 listopada 1996 r. o muzeach (t.j. Dz. U. 2017, poz. 972; dalej: u.o.m.), zostaną utracone przez właściciela. Warunkiem jest, zgodnie z art. 24a u.o.o.z., aby wraz z dokumentacją fotograficzną i opisem określającym indywidualne, pozwalające na identyfikację cechy, zostały wpisane do krajowego rejestru dóbr kultury na wniosek Policji, prokuratora, wojewódzkiego konserwatora zabytków, Naczelnego Dyrektora Archiwów Państwowych, właściciela rzeczy, o której mowa w ust. 2, lub osoby kierującej jednostką organizacyjną, w zbiorach albo zasobach której rzecz się znajdowała. Zgodnie z art. 24d u.o.o.z. nikt od dnia dokonania wpisu w krajowym rejestrze utraconych dóbr kultury nie może zasłaniać się nieznajomością danych ujawnionych w tym rejestrze (Michalak, Ginter 2016, 144-156). W odniesieniu do zapisów art. 3 ustawy o muzeach ustawodawca wskazuje, iż muzea mogą być tworzone dla jednej lub wielu dziedzin działalności człowieka oraz tworów natury. Dotyczy to ogólnie pojętych dóbr kultury, co w praktyce stanowi katalog otwarty, ponieważ każdy eksponat muzealny, bez względu na dziedzinę nauki lub sztuki, którą reprezentuje, podlega ochronie. Rozszerzając to o zapis art. 21 ust. 1 u.o.m., dowiadujemy się, że muzealiami są rzeczy ruchome i nieruchomości stanowiące własność muzeum i wpisane do inwentarza muzealiów. Muzealia bez względu na to, czy stanowią kolekcje czy zbiór rzeczy wpisanych do inwentarza muzeum, stanowią szeroko pojęte dobra narodowe, a co za tym idzie, posiadają ochronę prawną. Pojęcie „dobro kultury" pojawia się w ratyfikowanej konwencji sporządzonej w Paryżu 17 maja 1970 r. Konwencja ta dotyczy podejmowania środków w celu zapobiegania nielegalnemu wywozowi, przywozowi i przenoszeniu własności dóbr kultury. Zgodnie z art. 1 Konwencji za dobra kultury uważane są dobra, które ze względów religijnych lub świeckich uznawane są przez każde państwo za mające znaczenie dla archeologii, prehistorii, historii, literatury, sztuki lub nauki. Rejestracja utraconych muzealiów jest bardzo istotna, ułatwia ich odzyskanie nawet po wielu latach od ich kradzieży, również w przypadku ich nielegalnego wywozu poza granice naszego kraju (art. 109 u.o.o.z.).

Przykładem odzyskania utraconego dzieła sztuki niech będzie sprawa realizowana przez Wydział Kryminalny KWP w Łodzi. Funkcjonariusze wchodzący w skład Zespołu do Zwalczania Przestępczości Przeciwko Dziedzictwu Narodowemu uzyskali informacje, z których wynikało, że mieszkaniec okolic 
Łodzi kilkakrotnie, w różnych odstępach czasu, wystawiał na sprzedaż kradzione dzieła sztuki pochodzące z placówek muzealnych i obiektów sakralnych znajdujących się na terenie Polski. We wrześniu 2005 r. w jednym z domów aukcyjnych na terenie Warszawy pojawił się skradziony w lipcu 1978 r. w wyniku włamania do kościoła w Zuzeli zabytkowy barokowy pacyfikał (Karpowicz 2007, 10-11; Karpowicz 2009, 67-72). Rok później, w lipcu 2006 r. w domu aukcyjnym Rempex na terenie Warszawy pojawiły się dwa skradzione w czerwcu 1993 r. w wyniku włamania do Muzeum w Górkach Wielkich wachlarze autorstwa Wojciecha Kossaka (Szkaradnik, Jakubowski 2011, 27-30). Wykonane w 2006 r. czynności nie doprowadziły do ujawnienia i zabezpieczenia innych skradzionych zabytków. W 2007 r. Wydział Kryminalny KWP w Łodzi po przeanalizowaniu zebranych dotychczas informacji, które nie mogły być zbiegiem okoliczności, ustalił, że osoby wystawiające opisane przedmioty na sprzedaż nadal zajmują się obrotem dziełami sztuki. Zainteresowano się posiadłością, w której te osoby mieszkały. Był to rozległy obszar leśny o powierzchni kilkunastu hektarów, ogrodzony trzymetrowym płotem. Znajdował się tam drewniany XIX-wieczny dworek, ogród, fontanny, korty tenisowe, basen i inne zabudowania. Trzy schrony ukryte były w budynkach i pod ziemią. Teren był dodatkowo zabezpieczony monitoringiem oraz ochroną wyspecjalizowanej firmy. Czynności sprawdzające trwały półtora roku. W międzyczasie uzyskano informacje o osobach, które zamieszkują tę posiadłość. Ustalono również, że mają one dosyć dobre kontakty z przedstawicielami świata polityki, organów sprawiedliwości i mediów. Na terenie posesji znajdowała się też restauracja, która ze względu na ceny przyciągała jedynie zamożną klientelę. Z informacji od mieszkańców tej okolicy wynikało, że jest ona praktycznie opustoszała i wszyscy zastanawiają się, jak w ogóle prosperuje. Dowiedziano się ponadto, że właściciel może posiadać nielegalnie broń palną, a w swojej restauracji prawdopodobnie oferuje alkohol z nielegalnie przetworzonego spirytusu. Informacja o bezprawnym posiadaniu broni trafiła również do Zarządu Łódzkiego Centralnego Biura Śledczego, co ją jeszcze bardziej uprawdopodobniło. Po przeanalizowaniu wszystkich zebranych danych zaplanowano odpowiednie działania, sporządzono plan ich realizacji i na tej podstawie, po wykonaniu wszystkich niezbędnych czynności formalnych, przy udziale umundurowanych funkcjonariuszy, w lipcu 2009 r. udano się pod ustalony adres w miejscowości Sokolniki. Po wejściu na teren posesji umundurowani policjanci zabezpieczyli wjazd oraz znajdujące się tam budynki. Pozostałe osoby weszły do mieszkania, w którym do jednego z pomieszczeń sprowadzono wszystkich domowników. Przedstawiono im powód wizyty i okazano stosowny nakaz przeszukania. Pomimo wezwania do dobrowolnego oddania rzeczy pochodzących z przestępstwa lub służących do ich popełniania (w tym broni palnej oraz kradzionych obrazów), zebrane osoby stwierdziły, że nie posiadają takich przedmiotów, poza niewielką kolekcją zabytkowej broni palnej (fot. 1). 


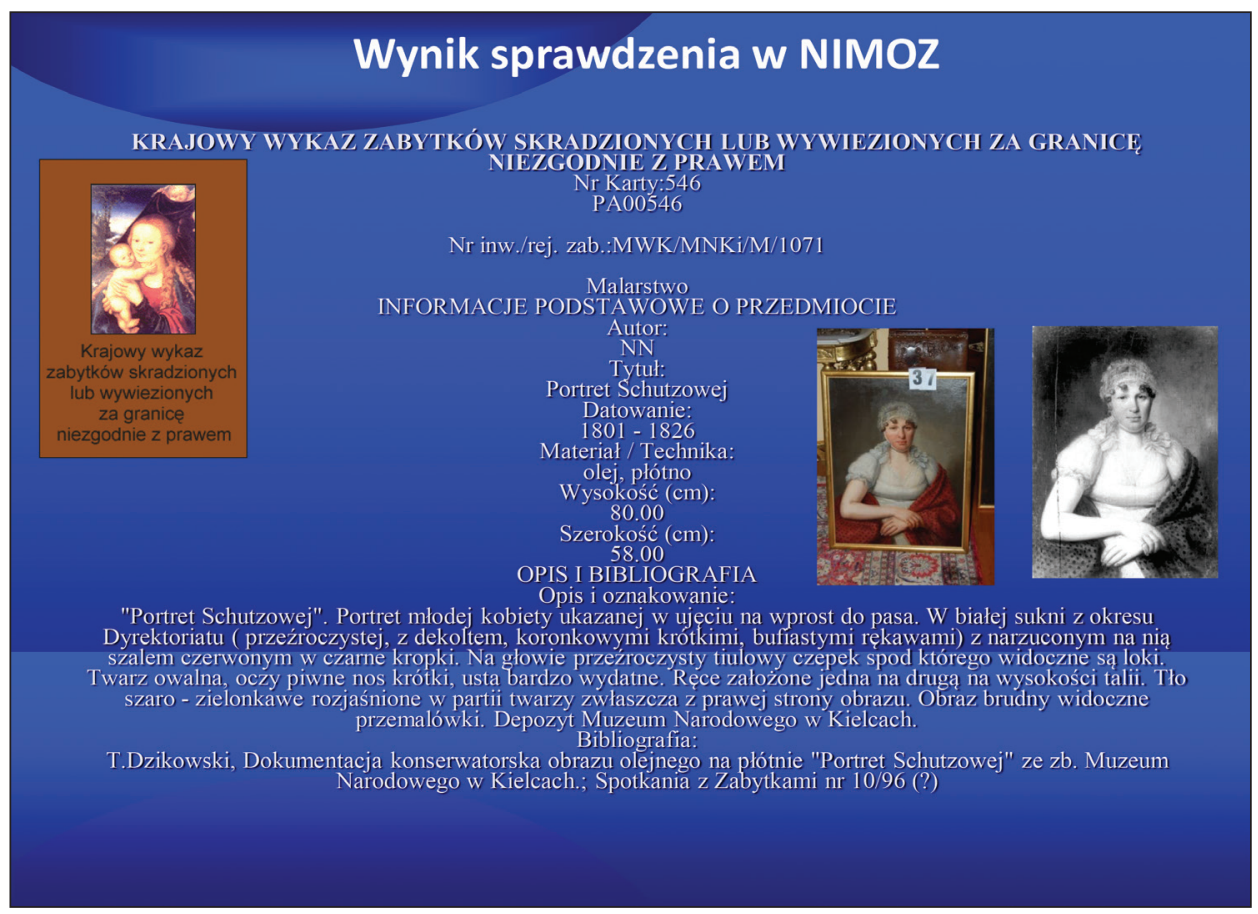

Fot. 1. Widok zarejestrowanych skradzionych zabytków w bazie internetowej Narodowego Instytutu Muzealnictwa i Ochrony Zbiorów (NIMOZ), 2009 r.

Źródło: opracowanie własne na podstawie strony internetowej www.skradzionezabytki.pl [dostęp 20.03.2010]

W trakcie przeszukiwania poszczególnych pomieszczeń, zarówno mieszkalnych, jak i gospodarczych, ujawniono trzy sztuki broni długiej jednostrzałowej bez zamków. W dalszej części domu, w sypialni na parterze, odkryto metalową kasetkę, we wnętrzu której znajdowały się dwa zamki od broni palnej. Jak wykazały dalsze działania, były one integralnymi częściami dwóch z trzech ujawnionych karabinów. Ponadto znaleziono współczesny rewolwer gazowy załadowany sześcioma sztukami amunicji. Dalsze czynności doprowadziły do wykrycia jeszcze jednej sztuki broni w postaci strzelby dwulufowej. Wszystkie te przedmioty zostały zabezpieczone protokolarnie.

Kolejnym etapem prowadzenia czynności było sprawdzenie informacji dotyczących posiadania dzieł sztuki pochodzących z przestępstwa. Po wykonaniu wstępnych oględzin przy użyciu katalogów dzieł skradzionych i poszukiwanych, funkcjonariusze Zespołu do Zwalczania Przestępczości Przeciwko Dziedzictwu Narodowemu Wydziału Kryminalnego KWP w Łodzi określili, że przynajmniej kilka spośród znajdujących się w budynku obrazów pochodzi z kradzieży. Figurowały one w krajowym wykazie zabytków skradzionych lub wywiezionych za granicę niezgodnie z prawem jako poszukiwane. Były to cztery dzieła sztuki 
malarskiej: portret mężczyzny (nieznanego autora), portret mężczyzny zatytułowany Poniatowski (nieznanego autora), portret młodej kobiety zatytułowany Portret Schutzowej (autorstwa nieznanego malarza) oraz widok z drewnianym kościołem w Grochowie autorstwa Juliusza Kossaka (fot. 2-4).
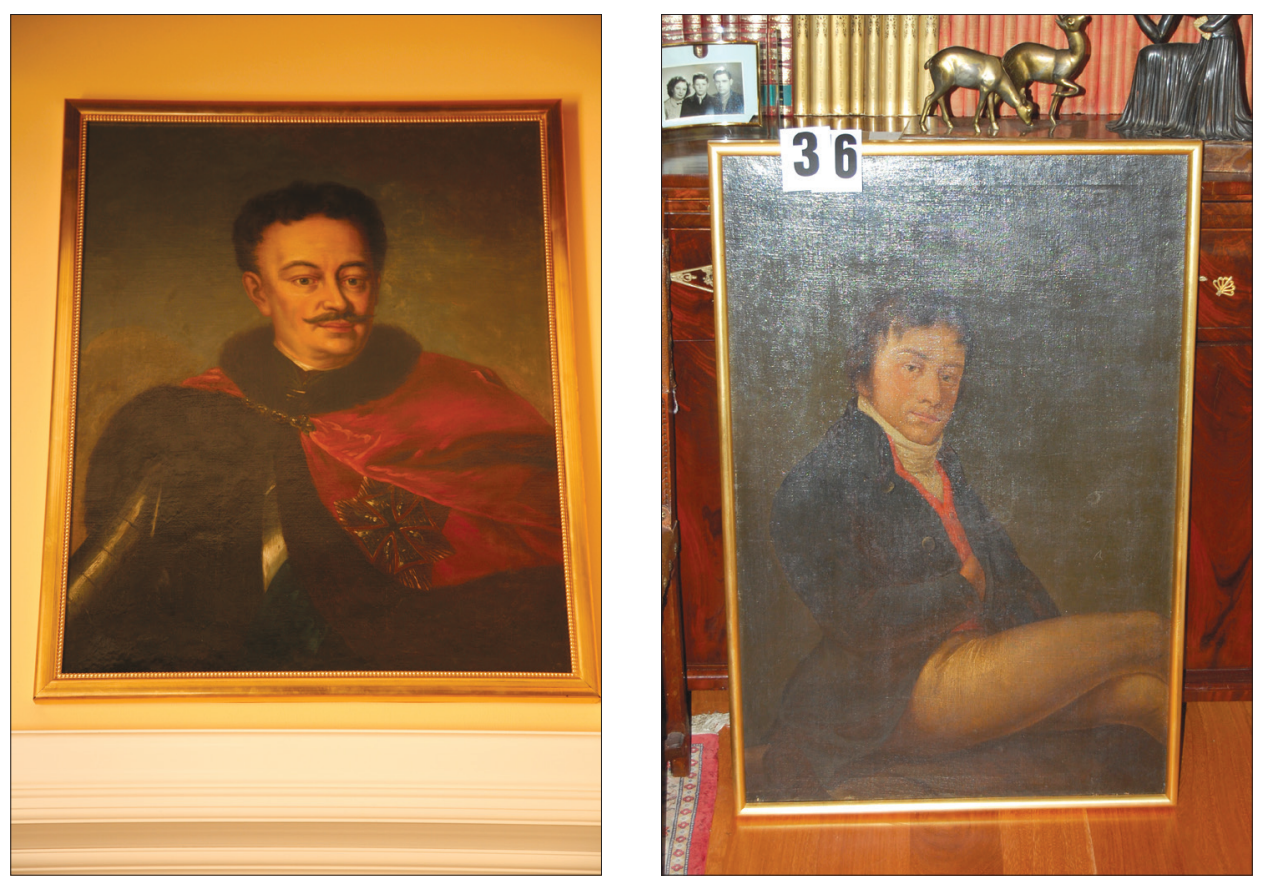

Fot. 2-3. Zabezpieczone w trakcie czynności obrazy pochodzące z przestępstwa, Sokolniki, 2009 r.

Źródło: archiwum prywatne autora

Obrazy te zostały utracone w wyniku kradzieży z włamaniem do Muzeum Wsi Kieleckiej w Tokarni w 1996 r. oraz do Muzeum Zofii Kossak w Górkach Wielkich w 1993 r. Podjęto decyzję o zarekwirowaniu całej kolekcji celem wykonania szczegółowych badań. W sumie zabezpieczono 67 sztuk obrazów oraz jedną figurę sakralną. Zdejmowanie ze ścian i opisywanie przedmiotów odbywało się przy współudziale technika kryminalistyki oraz przedstawiciela Muzeum Sztuki w Łodzi, gdzie rzeczy te, po opakowaniu w folie i gąbkę, zostały zdeponowane do czasu zakończenia postępowania ${ }^{2}$.

Nielegalne posiadanie broni i amunicji, z którym mieliśmy do czynienia w opisanej sprawie, jest przestępstwem zgodnie z art. $263 \S 2$ k.k. Na jej posiadanie w celach kolekcjonerskich zgodnie z art. 10 u.o.b.a. wymagane jest

\footnotetext{
${ }^{2}$ Sprawa 4 Ds. 997/09, prowadzona przez Prokuraturę Rejonową w Zgierzu.
} 
pozwolenie. Trzeba w tym przypadku zaznaczyć, że przedmioty te, pomimo iż ich posiadanie jest zabronione, również mogą stanowić zabytki zgodnie $\mathrm{z}$ art. 3 ust. 1 i 3 u.o.o.z. Posiadanie przedmiotów, a w tym wypadku dzieł sztuki, pochodzących z przestępstwa kradzieży jest również przestępstwem, zgodnie z art. $291 \S 1$ k.k. Finalnie obrazy wróciły do właścicieli, po 16 latach do Muzeum Zofii Kossak w Górkach Wielkich oraz po 13 latach do Muzeum Wsi Kieleckiej w Tokarni. Zabytkowa broń palna trafiła do jednej z placówek muzealnych na terenie Łodzi.

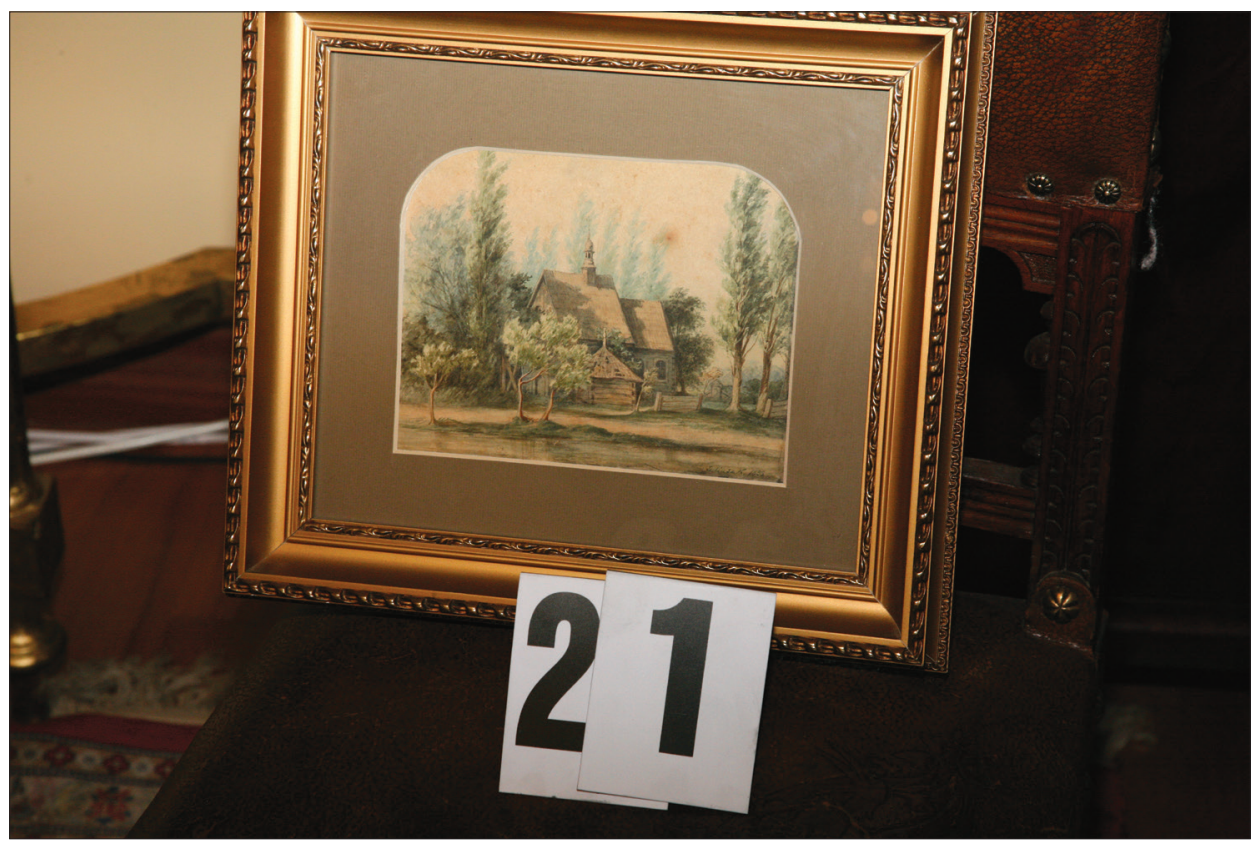

Fot. 4. Zabezpieczony w trakcie czynności obraz pochodzący z przestępstwa, Sokolniki, 2009 r.

Źródło: archiwum prywatne autora

Zapotrzebowanie na wszelkiego rodzaju przedmioty o wartości historycznej, zabytkowej czy sakralnej obrazuje kolejna sprawa, którą zajmowali się funkcjonariusze Zespołu Zwalczania Przestępczości Przeciwko Dziedzictwu Narodowemu Wydziału Kryminalnego KWP w Łodzi, tym razem we współpracy z Wydziałem Kryminalnym Komendy Miejskiej Policji w Skierniewicach.

W wyniku złożonych czynności operacyjnych w czerwcu 2013 r., w domu jednorodzinnym pod Pruszczem Gdańskim, funkcjonariusze z garnizonu łódzkiego zabezpieczyli obraz autorstwa Kazimierza Alchimowicza zatytułowany Portret Józefa Chetmońskiego, stanowiący własność Muzeum Sztuki w Łodzi, który został skradziony w 1991 r. z wystawy w trakcie włamania do Muzeum Ogrodnictwa w Skierniewicach. Obraz również został zarejestrowany w ogólnopolskiej 
bazie funkcjonującej jako krajowy wykaz zabytków skradzionych lub wywiezionych za granicę niezgodnie z prawem, prowadzonej przez Narodowy Instytut Muzealnictwa i Ochrony Zbiorów (fot. 5).

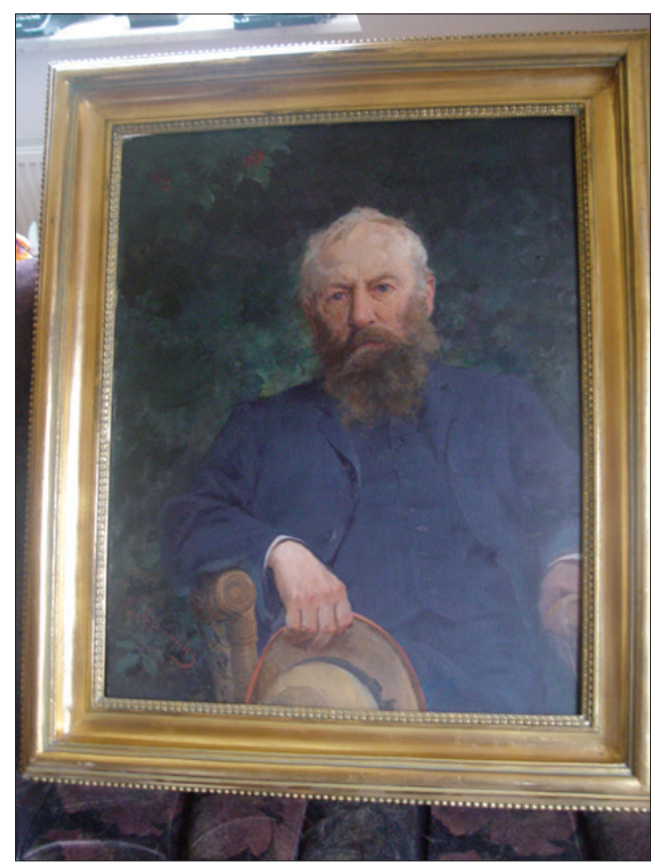

Fot. 5. Zabezpieczony w trakcie czynności obraz pochodzący z przestępstwa, Pruszcz Gdański, 2013 r.

Źródło: archiwum prywatne autora

Pierwszą informację na temat pojawienia się oferty sprzedaży skradzionego obrazu powzięli pod koniec maja 2013 r. funkcjonariusze Wydziału Kryminalnego KMP w Skierniewicach, natychmiast powiadamiając kolegów z Wydziału Kryminalnego KWP w Łodzi. Podjęte wspólne działania doprowadziły funkcjonariuszy na teren województwa pomorskiego. W trakcie złożonych czynności ustalono również dane osobowe i adresy osób mających związek z oferowanym obrazem, a następnie dokonano w tych miejscach przeszukań ${ }^{3}$. Zabezpieczony obraz poddano badaniom, do których powołano biegłych z zakresu historii sztuki i malarstwa. Stwierdzili oni jego autentyczność. Ponadto pracownicy muzeum podczas badań rozpoznali fragmenty naklejek muzealnych na zabezpieczonej ramie. Obraz wraz z ramą wrócił po 22 latach do Muzeum Sztuki w Lodzi. Sprawa zakończyła się postawieniem zarzutów z art. 286 § 1 k.k. oraz art. 291 k.k.

\footnotetext{
${ }^{3}$ Sprawa Ds. 1148/13 prowadzona przez Prokuraturę Rejonową w Skierniewicach.
} 
W grudniu 2011 r. funkcjonariusze Zespołu do Walki z Przestępczością Przeciwko Dziedzictwu Narodowemu Wydziału Kryminalnego KWP w Łodzi w trakcie prowadzonych czynności ujawnili i zabezpieczyli na terenie galerii sztuki w Łodzi obraz autorstwa Teodora Axentowicza, zatytułowany Kobieta w pawich piórach. Obraz znajdował się w wykazie strat wojennych prowadzonym przez Ministerstwo Kultury oraz był zarejestrowany w wykazie skradzionych zabytków, prowadzonym przez NIMOZ. Obraz zaginął w 1939 r. w niewyjaśnionych okolicznościach w czasie działań wojennych. Był on wtedy własnością Towarzystwa Zachęty Sztuk Pięknych w Warszawie. Zabezpieczony w trakcie czynności obraz poddano ekspertyzom kryminalistycznym. Powołano biegłych z zakresu historii sztuki i malarstwa, którzy stwierdzili jego autentyczność. Finalnie obraz po 72 latach wrócił do Muzeum Narodowego w Warszawie, który po II wojnie światowej był prawnym spadkobiercą zbiorów po Towarzystwie Zachęty ${ }^{4}$ (fot. 6).

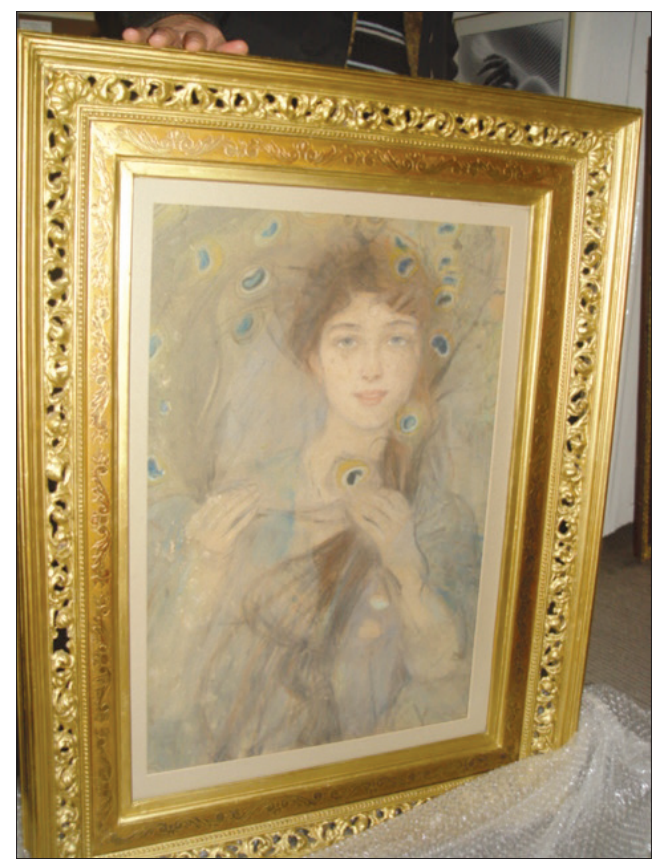

Fot. 6. Zabezpieczony w trakcie czynności obraz będący stratą wojenną, Łódź, 2011 r.

Źródło: archiwum prywatne autora

Przedstawione powyżej przykłady to tylko mały wycinek problematyki związanej z przestępstwami przeciwko szeroko rozumianemu dziedzictwu narodowemu. $\mathrm{Z}$ powodu różnych uwarunkowań i specyfiki zagadnienia trudno jest określić

\footnotetext{
${ }^{4}$ Sprawa 2 Ds. 2455/11, prowadzona przez Prokuraturę Rejonową w Łodzi.
} 
właściwą liczbę wszystkich zdarzeń. Często zabytkowe przedmioty mogą znajdować się w opuszczonych fabrykach, pałacach, przydrożnych kaplicach, parkach, na cmentarzach i w innych obiektach, które trudno nawet wymienić, a wiedza o ich utracie dociera zbyt późno. Przeważnie są to miejsca niedozorowane, a ich wyposażenie nie jest zewidencjonowane. Właściciele lub ich administratorzy sami dokładnie nie wiedzą, co się tam znajduje i jaką przedstawia wartość historyczną, artystyczną lub naukową. Również, pomimo stosowanych zabezpieczeń, na kradzieże narażone są kolekcje osób prywatnych i wystawy muzealne. Liczba poszukujących i chętnych do nabycia wszelkiego rodzaju przedmiotów o wartości historycznej i artystycznej czy sakralnej wciąż wzrasta, nieadekwatnie do liczby zabytków i dzieł sztuki obecnych na rynku kolekcjonerskim. Wzrost ich wartości rynkowej stanowi zachętę do przestępstwa i pożywkę dla rozwijającego się rynku falsyfikatów. Należy pamiętać, że dobra kultury są niezwykle ważnym elementem w kształtowaniu świadomości kulturowej, co dodatkowo podnosi ich wartość. Na podstawie obserwacji opartej na praktyce można odnieść wrażenie, że rynek sztuki w Polsce jest jeszcze niedojrzały w porównaniu z innymi krajami europejskimi i towarzyszy mu wiele nieprawidłowości. Trzeba jednak pamiętać, że ma on ścisły związek z ochroną zabytków w Polsce. To właśnie kolekcjonerzy, antykwariusze, eksperci od zabytków i dzieł sztuki są jego główną siłą napędową, jednak ogromne znacznie w tym procesie ma także skuteczne działanie Policji, organów prokuratorskich i sądowniczych. Podniesienie znaczenia ich roli na rynku sztuki niewątpliwie poprawi stan ochrony prawnej zabytków.

\section{BIBLIOGRAFIA}

Gadecki, Bartłomiej. 2014. Ustawa o ochronie zabytków i opiece nad zabytkami. Art. 108-120. Przepisy karne. Komentarz. Warszawa: C.H. Beck.

Karpowicz, Mirosław. 2007. „Odzyskany po 28 latach”. Cenne, Bezcenne, Utracone 4 (53): 10-11.

Karpowicz, Mirosław. 2009. „Dopóki jest nadzieja - po półwieczu barokowy relikwiarz wraca do Zuzeli”. W Policja w ochronie zabytków sakralnych. Red. Zbigniew Judycki, Mirosław Karpowicz. 67-72. Lublin: Towarzystwo Naukowe KUL.

Kocewiak, Sławomir, Piotr Ogrodzki, Jacek Rulewicz. 2002. Vademecum zabezpieczenia muzeów. Warszawa: Pagina.

Michalak, Anna, Artur Ginter. 2016. Ustawa o ochronie zabytków i opiece nad zabytkami. Komentarz. Warszawa: Wolters Kluwer.

Rudnicki, Grzegorz, Jolanta Rudnicka, Stanisław Rudnicki. 2016. Kodeks cywilny. Komentarz. T. II. Własność i inne prawa rzeczowe. Red. Jacek Gudowski. Warszawa: Wolters Kluwer.

Szkaradnik, Tomasz, Olgierd Jakubowski. 2011. „Spór o własność wachlarzy Kossaków skradzionych z Muzeum w Górkach Wielkich”. Cenne, Bezcenne, Utracone 4 (69): 27-30.

\section{Akty prawne}

Dziennik Urzędowy Komendy Głównej Policji 2004, Nr 21, poz. 135.

Dziennik Urzędowy Komendy Głównej Policji 2005, Nr 6, poz. 29.

Konwencja podpisana w Paryżu dotycząca podejmowania środków w celu zapobiegania nielegalnemu wywozowi, przywozowi i przenoszeniu własności dóbr kultury z 17 maja 1970 r. (Dz. U. 1974, Nr 20, poz. 106). 
Ustawa z dnia 23 kwietnia 1964 r. - Kodeks cywilny (t.j. Dz. U. 2017, poz. 459).

Ustawa z dnia 21 listopada 1996 r. o muzeach (t.j. Dz. U. 2017, poz. 972).

Ustawa z dnia 6 czerwca 1997 r. - Kodeks karny (t.j. Dz. U. 2017, poz. 2204).

Ustawa z dnia 21 maja 1999 r. o broni i amunicji (t.j. Dz. U. 2017, poz. 1839).

Ustawa z dnia 23 lipca 2003 r. o ochronie zabytków i opiece nad zabytkami (t.j. Dz. U. 2017, poz. 2187).

Ustawa z dnia 20 lutego 2015 r. o rzeczach znalezionych (Dz. U. 2015, poz. 397).

\title{
Adam Grajewski
}

\section{RECOVERY OF STOLEN CULTURAL PROPERTY AFTER YEARS OF THEFT}

\begin{abstract}
Nowadays, demand and will to possess works of art and monuments is rapidly increasing, but at the same time the quantity of them is not increasing to meet the demand. Theft of art does not cause decrease in its value, on the contrary, its long-term storage even increases the value. This situation results in an increase of its market value, which becomes the tempting object of the crime. Criminal groups have also recognized the situation and they well know needs of the collector's market and take advantage of them. In the 90-ies there were many burglaries at sacral buildings, museums and private houses in which mainly works of art were stolen. Currently, we can observe that the pieces of art, which were lost in those years appear more and more often on the art market.
\end{abstract}

Keywords: museum, collection, theft, exhibit, forensic. 